\title{
Plasma Calcium and Magnesium in Newborn Babies
}

\author{
D. R. HARVEY, LESLEY V. COOPER, and J. F. STEVENS \\ From the Neonatal Research Unit, Institute of Child Health, Hammersmith Hospital, London W12
}

Harvey, D. R., Cooper, L. V., and Stevens, J. F. (1970). Archives of Disease in Childhood, 45, 506. Plasma calcium and magnesium in newborn babies. Normal values for plasma calcium and magnesium levels during the first week of life, in breast- and bottle-fed babies, have been determined. It has been shown on the sixth day that plasma levels of calcium, magnesium, and protein are all significantly lower in bottle-fed babies than in breast-fed babies, while the reverse is true of the plasma inorganic phosphorus.

The normal babies have been compared with 30 babies who had convulsions, beginning towards the end of the first week of life. In only six of the babies was the plasma calcium outside our normal range and only four had abnormally low magnesium levels. As so many of these babies had calcium and magnesium levels within the normal range it must seriously be questioned whether hypocalcaemia or hypomagnesaemia could have been the sole cause of the convulsions.

In order to establish normal values for the first week of life, calcium and magnesium have been measured in samples of plasma for normal infants who were either breast- or bottle-fed.

Convulsions beginning on the 5 th to 8 th days of life are often attributed to hypocalcaemia (Bakwin, 1937) or hypomagnesaemia (Davis, Harvey, and $\mathrm{Yu}, 1965)$. A group of babies with convulsions at the end of the first week has been compared with the normal infants.

\section{Material and Methods}

Two maternity units were used for this survey. The first series was conducted at Hammersmith Hospital from June to September 1967; the blood was collected immediately before the 9 a.m. feed from normal babies on the first seven days of life. Samples obtained from 85 babies were not consecutive though most babies were bled more than once. Heel-prick samples were obtained without squeezing and were centrifuged and separated immediately; any grossly haemolysed samples were discarded. Heparin was used as an anticoagulant. The babies' weights ranged from 2300 to 4460 g., and their gestational ages from 38 to 42 weeks. They were either entirely breast fed, apart from an initial feed of glucose and water, or were fed on an evaporated milk formula ('Carnation Milk'). This was diluted 1 part with $2 \frac{1}{2}$ parts of water, and given in volumes of 90-160 $\mathrm{ml} . / \mathrm{kg}$. per 24 hours on the second day, increasing gradually to $140-160 \mathrm{ml} / \mathrm{kg}$. per 24 hours on the sixth day. In this dilution the milk contained: phosphorus $67 \mathrm{mg} . / 100 \mathrm{ml}$.; calcium $76 \mathrm{mg} . / 100 \mathrm{ml}$., and vitamin D 28 I.U. $/ 100 \mathrm{ml}$.

Received 16 December 1969.
The second series was conducted at Hillingdon Hospital from April to September 1968. Normal babies of birthweight 2400 to $4465 \mathrm{~g}$., and gestational age 37 to 42 weeks were bled at 9 a.m. on the sixth day of life. Blood was collected and processed in the same way as in the first series, and in addition arterialized capillary blood was taken into sealed heparinized capillary tubes for blood gas analysis. In this series babies were either breast fed, apart from a supplement of $15-45 \mathrm{ml}$. of halfcream dried milk formula ('Cow and Gate') on each of the first two nights, or were entirely bottle fed on the same dried milk formula. Half-cream milk was used for the first four days and full-cream thereafter, in amounts increasing from $15-30 \mathrm{ml}$./feed on the first day of life to $90-105 \mathrm{ml}$./feed on the sixth day. This milk contained: phosphorus $66 \mathrm{mg} . / 100 \mathrm{ml}$.; calcium 49 $\mathrm{mg} . / 100 \mathrm{ml}$., and vitamin D $37 \mathrm{I} . \mathrm{U} . / 100 \mathrm{ml}$.

In all cases the mother's permission was obtained before blood was taken.

All the babies at the Hammersmith Hospital, who had convulsions beginning on the 5th to 8th days of life between October 1965 and November 1968, had their plasma calcium, magnesium, and phosphorus levels measured. There were 30 of these babies and they have been compared with the normals. Blood was taken from these babies in the same way as the normals before any treatment was given. In addition, the usual investigations for neonatal convulsions were performed, including a lumbar puncture in all cases. The convulsions were, as usual in the newborn, of the multifocal type described by Harris and Tizard (1960) and seen with hypocalcaemia by Keen (1969).

Plasma calcium and magnesium were estimated on an EEL atomic absorption spectrophotometer. The method used was a modification of that developed by Willis (1960) using EDTA solution as a diluent. This 
TABLE I

Series I: Plasma Calcium and Magnesium Levels in Normal Babies

\begin{tabular}{|c|c|c|c|c|c|c|c|c|}
\hline & & Day 1 & Day 2 & Day 3 & Day 4 & Day 5 & Day 6 & Day 7 \\
\hline $\begin{array}{l}\text { Calcium (mg./100 ml.) } \\
\text { Breast-fed } \\
\text { Bottle-fed }\end{array}$ & $\begin{array}{l}\text { Mean } \\
\text { Range } \\
\text { No. } \\
\text { Mean } \\
\text { Range } \\
\text { No. } \\
\\
\text { Mean } \\
\text { Range } \\
\text { No. }\end{array}$ & $\begin{array}{l}9 \cdot 1 \\
5 \cdot 8-12 \cdot 6 \\
16\end{array}$ & $\begin{array}{l}7 \cdot 5 \\
5 \cdot 2-9 \cdot 8 \\
9 \\
7 \cdot 2 \\
5 \cdot 8-8 \cdot 6 \\
9 \\
7 \cdot 6 \\
5 \cdot 2-9 \cdot 8 \\
19\end{array}$ & $\begin{array}{l}9 \cdot 3 \\
7 \cdot 2-11 \cdot 2 \\
9 \\
8 \cdot 6 \\
7 \cdot 4-9 \cdot 8 \\
9 \\
7 \cdot 6 \\
7 \cdot 2-11 \cdot 2 \\
18\end{array}$ & $\begin{array}{l}8 \cdot 6 \\
7 \cdot 2-10 \cdot 2 \\
10 \\
8 \cdot 0 \\
5 \cdot 8-11 \cdot 4 \\
10 \\
\\
8 \cdot 6 \\
5 \cdot 8-11 \cdot 4 \\
20\end{array}$ & $\begin{array}{l}8 \cdot 3 \\
2 \cdot 4-12 \cdot 6 \\
8 \\
7 \cdot 4 \\
6 \cdot 0-8 \cdot 4 \\
10 \\
8 \cdot 0 \\
2 \cdot 4-12 \cdot 6 \\
18\end{array}$ & $\begin{array}{l}8 \cdot 6 \\
6 \cdot 4-10 \cdot 2 \\
9 \\
7 \cdot 6 \\
6 \cdot 4-9 \cdot 0 \\
11 \\
8 \cdot 4 \\
6 \cdot 4-10 \cdot 2 \\
20\end{array}$ & $\begin{array}{l}8 \cdot 9 \\
6 \cdot 8-11 \cdot 4 \\
6 \\
8 \cdot 6 \\
6 \cdot 0-11 \cdot 4 \\
9 \\
8 \cdot 6 \\
6 \cdot 0-11 \cdot 4 \\
15\end{array}$ \\
\hline $\begin{array}{l}\text { Magnesium (mg./100 ml.) } \\
\text { Breast-fed } \\
\text { Bottle-fed }\end{array}$ & $\begin{array}{l}\text { Mean } \\
\text { Range } \\
\text { No. } \\
\text { Mean } \\
\text { Range } \\
\text { No. } \\
\\
\text { Mean } \\
\text { Range } \\
\text { No. }\end{array}$ & $\begin{array}{l}1 \cdot 30 \\
0 \cdot 9-1 \cdot 6 \\
16\end{array}$ & $\begin{array}{l}1 \cdot 20 \\
0 \cdot 9-1 \cdot 8 \\
9 \\
1 \cdot 30 \\
1 \cdot 1-1 \cdot 5 \\
9 \\
\\
1 \cdot 20 \\
0 \cdot 9-1 \cdot 8 \\
19\end{array}$ & $\begin{array}{l}1 \cdot 40 \\
0 \cdot 9-1 \cdot 7 \\
9 \\
1 \cdot 30 \\
0 \cdot 7-1 \cdot 6 \\
9 \\
\\
1 \cdot 40 \\
0 \cdot 7-1 \cdot 7 \\
18\end{array}$ & $\begin{array}{l}1 \cdot 30 \\
1 \cdot 1-1 \cdot 6 \\
10 \\
1 \cdot 20 \\
1 \cdot 0-1 \cdot 4 \\
10 \\
1 \cdot 40 \\
1 \cdot 0-1 \cdot 6 \\
20\end{array}$ & $\begin{array}{l}1 \cdot 10 \\
0 \cdot 42-1 \cdot 86 \\
8 \\
1 \cdot 00 \\
1 \cdot 0-1 \cdot 32 \\
10 \\
1 \cdot 06 \\
0 \cdot 42-1 \cdot 86 \\
18\end{array}$ & $\begin{array}{l}1 \cdot 60 \\
1 \cdot 1-1 \cdot 71 \\
9 \\
1 \cdot 10 \\
0 \cdot 9-1 \cdot 4 \\
11 \\
1 \cdot 30 \\
0 \cdot 9-1 \cdot 7 \\
20\end{array}$ & $\begin{array}{l}1 \cdot 36 \\
1 \cdot 1-1 \cdot 6 \\
6 \\
1 \cdot 15 \\
0 \cdot 8-1 \cdot 8 \\
9 \\
\\
1 \cdot 37 \\
0 \cdot 8-1 \cdot 8 \\
15\end{array}$ \\
\hline
\end{tabular}

Calcium $1 \mathrm{mEq} / 1 .=2 \mathrm{mg} . / 100 \mathrm{ml}$. Magnesium $1 \mathrm{mEq} / 1 .=1 \cdot 2 \mathrm{mg} \cdot / 100 \mathrm{ml}$. No. = number of samples.

method has been shown in our laboratory to give results comparable to those obtained by flame photometry. Plasma inorganic phosphorus and protein were estimated by ultra-micro-techniques (Stevens, 1965). The blood $p \mathrm{H}, \mathrm{PCO}_{2}$, and standard bicarbonate were measured by the Astrup technique (Siggaard Andersen et al., 1960).

\section{Results}

Normal babies. The results from the first series are shown in Table $\mathrm{I}$.

The plasma calcium level is variable; dropping on the second day, rising on the third day, and falling again on the fourth and fifth days. The only daily variations which are statistically significant are those between days 1 and 2, 2 and 3, 3 and 4, and 2 and 7. On all days after breast feeding had been established the breast-fed babies had higher plasma calcium levels than the bottle-fed babies. However, when subdivided according to the type of feeding, the numbers were too small and the range too wide to permit a valid statistical analysis. For this reason we have expressed the results as the mean and range for each day. The magnesium levels were also lower in the bottle-fed babies towards the end of the first week.

The differences between the breast-fed and bottlefed babies appeared to be maximal on the sixth day, and it was for this reason that we undertook the second series. Table II shows the results obtained; the number of babies in each group varies slightly

\section{TABLE II}

Plasma Calcium, Magnesium, Inorganic Phosphate, and Total Protein on 6th Day of Life in Normal Babies.

\begin{tabular}{|c|c|c|c|c|c|}
\hline $\begin{array}{l}\text { Type of } \\
\text { Feeding }\end{array}$ & & $\begin{array}{c}\text { Calcium } \\
\text { (mg./100 ml.) }\end{array}$ & $\begin{array}{l}\text { Magnesium } \\
\text { (mg./100 ml.) }\end{array}$ & $\begin{array}{l}\text { Inorganic Phosphate } \\
\text { (mg./100 ml.) }\end{array}$ & $\begin{array}{l}\text { Total Protein } \\
\text { (g./100 ml.) }\end{array}$ \\
\hline Bottle-fed & $\begin{array}{l}\text { Mean } \\
\text { Standard deviation } \\
\text { Range } \\
\text { No. }\end{array}$ & $\begin{array}{l}8 \cdot 8 \\
1 \cdot 9 \\
3 \cdot 8-11 \cdot 2 \\
24\end{array}$ & $\begin{array}{l}1 \cdot 40 \\
0 \cdot 25 \\
0 \cdot 85-1 \cdot 90 \\
26\end{array}$ & $\begin{array}{l}8 \cdot 25 \\
3 \cdot 35 \\
4 \cdot 60-21 \cdot 00 \\
25\end{array}$ & $\begin{array}{l}5 \cdot 05 \\
0 \cdot 55 \\
3 \cdot 40-5 \cdot 80 \\
23\end{array}$ \\
\hline Breast-fed & $\begin{array}{l}\text { Mean } \\
\text { Standard deviation } \\
\text { Range } \\
\text { No. }\end{array}$ & $\begin{array}{l}10 \cdot 1 \\
1 \cdot 2 \\
8 \cdot 0-12 \cdot 4 \\
24\end{array}$ & $\begin{array}{l}1 \cdot 70 \\
0 \cdot 20 \\
1 \cdot 20-2 \cdot 05 \\
29\end{array}$ & $\begin{array}{l}6 \cdot 25 \\
1 \cdot 20 \\
4 \cdot 10-9 \cdot 80 \\
27\end{array}$ & $\begin{array}{l}5 \cdot 70 \\
0 \cdot 90 \\
4 \cdot 30-8 \cdot 30 \\
30\end{array}$ \\
\hline $\mathbf{p}$ & & $0.01-0.005$ & $<0.001$ & $0.01-0.005$ & $0.005-0.001$ \\
\hline
\end{tabular}

p was calculated using a 2-tailed significance test for difference between the means. No. = number of samples. 
because in a few cases there was insufficient blood for all estimations. Each group of figures is normally distributed on an arithmetic scale, and therefore direct statistical analysis is justified. Using a two-tailed significance test, the plasma calcium, magnesium, and protein levels were all significantly lower $(p<0.05)$ in the bottle-fed babies than in the breast-fed babies. The reverse was true for the plasma inorganic phosphorus.

No significant differences were shown between male and female babies. There were also no significant differences in $p \mathrm{H}, \mathrm{PCO}_{2}$, and standard bicarbonate between the breast- and bottle-fed groups (mean $\pm S D$, breast-fed babies $p \mathrm{H} \mathrm{7.35}$ $\pm 0.04 \mathrm{PCO}_{2}(\mathrm{~mm}$. $\mathrm{Hg}) 40.63 \pm 4.30$, standard bicarbonate $(\mathrm{mEq} / \mathrm{l}$.) $22.07 \pm 1.68$; bottle-fed babies $p \mathrm{H} 7 \cdot 34 \pm 0.04, \mathrm{PcO}_{2} 42 \cdot 25 \pm 11 \cdot 34$, standard bicarbonate $22 \cdot 58 \pm 3 \cdot 77$ ).

Table III shows the values of the correlation coefficient $(r)$. The probability levels indicate that calcium and magnesium, magnesium and phosphorus, magnesium and protein, calcium and phosphorus are all significantly related. Protein was not significantly related with either calcium or phosphorus.

TABLE III

Series 2: Comparison of Values Obtained on 6th Day of Life in Bottle- and Breast-fed Babies

\begin{tabular}{l|c|c|c}
\hline & $\begin{array}{c}\text { No. } \\
\text { of } \\
\text { Samples }\end{array}$ & $\begin{array}{c}\text { Correlation } \\
\text { Coefficient } \\
\mathrm{r}\end{array}$ & $\mathrm{p}$ \\
\hline Calcium-magnesium & 47 & +0.469 & $<0.001$ \\
Calcium-phosphate & 54 & -0.335 & $0.05-0.02$ \\
Magnesium-phosphate & 52 & -0.316 & $0.05-0.01$ \\
Phosphate-protein & 52 & +0.148 & $>0.1$ \\
Magnesium-protein & 54 & -0.340 & $0.05-0.01$ \\
Calcium-protein & 48 & -0.265 & $0.1-0.05$ \\
& & & \\
\hline
\end{tabular}

Babies with convulsions. The values for these babies are compared with the normal range in the Fig. As can be seen, the plasma phosphorus levels are evenly distributed within the range for normal babies. There are only six cases in which the calcium falls outside the normal range ( $>2 S D$ below the mean), but the mean plasma calcium level for the convulsing babies is $6.3 \mathrm{mg} .100 \mathrm{ml}$., a significant difference $(p<0.001)$ from the mean of $8.4 \mathrm{mg}$. $100 \mathrm{ml}$. for normal babies of the same age. Similarly, in only four cases was the magnesium level outside the normal range, though the mean was $1.15 \mathrm{mg} . / 100 \mathrm{ml}$. compared to $1.31 \mathrm{mg}$. $/ 100 \mathrm{ml}$. for the normal babies ( $p=0.01$ to 0.02 ).

No other cause for convulsions was found in any of the 30 babies. One baby who had a plasma calcium of $6 \mathrm{mg} . / 100 \mathrm{ml}$. and magnesium $1.3 \mathrm{mg}$./

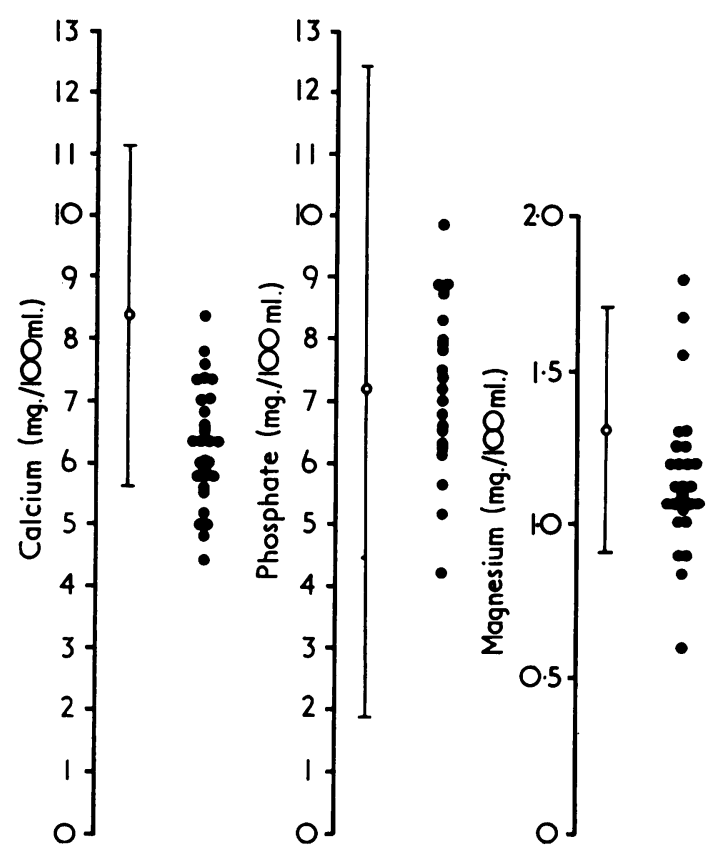

FIG.-Lowest levels of calcium recorded with accompanying plasma inorganic phosphorus and magnesium levels in babies having fits on the 5th-8th day of life (O), compared with the mean $\pm 2 S D$ of normal babies of the same age.

$100 \mathrm{ml}$. when he first had a convulsion, developed meningitis two days later. In all other cases the cerebrospinal fluid was normal.

\section{Discussion}

The pattern of the plasma calcium values during the neonatal period-a fall in the first $\mathbf{4 8}$ hours, a rise, and then another fall at the end of the first week-has been reported by other authors (Todd, Chuinard, and Wood, 1939; Graham, Barness, and György 1953; Gittleman, Pincus, and Schmertzler, 1964; Acharya and Payne, 1965). Cow's milk is known to produce lower calcium levels (Graham et al., 1953; Oppé and Redstone, 1968), as does vitamin D (Gittleman et al., 1964). However, there has been no real agreement on the actual level of calcium; our figures are lower than most of those reported, though Spivek (1956) had a group of 31 babies with a mean serum calcium of $7.4 \mathrm{mg}$. $/ 100$ $\mathrm{ml}$. on the fifth day. The plasma magnesium levels are also lower than other series reported (Anast, 1964; Bajpai et al., 1966; Kobayashi, 1967), though they were using different techniques.

The real importance of these figures lies in the 
comparison with the babies who had convulsions. For over three decades $8 \mathrm{mg}$./100 ml. has generally been accepted as the lower limit of normal for the plasma calcium in the newborn (Bakwin, 1937), but we consider this figure to be unrealistically high. The subject of hypocalcaemia and neonatal fits has been recently reviewed by Keen (1969) who accepted a figure of $7.5 \mathrm{mg} . / 100 \mathrm{ml}$. as normal. Only 6 of our 30 babies had values outside our normal range. One could doubt the relevance of the low plasma calcium to the convulsions except that the mean calcium for the group was significantly lower than the normal mean for this age. Presumably some other factor must determine whether a baby will have a convulsion at a given plasma calcium or magnesium level. It is possible that the ionized calcium level is more important than the total calcium which we have measured.

The apparent increase in the incidence of convulsions attributed to hypocalcaemia may have been due to the comparatively large volumes of milk which the babies in our wards were receiving at this time (Baum, Cooper, and Davies, 1968). We consider our present regimen of $30 \mathrm{ml} . / \mathrm{kg}$. per 24 hours on the first two days of life, gradually increasing to $150 \mathrm{ml} . / \mathrm{kg}$. per 24 hours by the end of the first week, of evaporated milk diluted 1 part plus $2 \frac{1}{2}$ parts of water, to be more suitable for full-term normal weight-for-dates babies.

D.R.H. was supported by a Percy J. Neate Fellowship of the Worshipful Company of Clothworkers. We thank the Sir William Coxen Trust Fund for laboratory facilities.

The babies were under the care of Dr. J. Scopes at the Hammersmith Hospital; and Dr. H. V. L. Finlay and Dr. S. M. Tucker at the Hillingdon Hospital. We are very grateful to them and also to the sisters and nursing staff of the two maternity units.

We should also like to thank Professor J. P. M. Tizard,
Dr. Pamela Davies, and Dr. Heather Shelley for their advice and criticism in the preparation of this paper.

\section{REFERENCES}

Acharya, P. T., and Payne, W. W. (1965). Blood chemistry of normal full-term infants in the first $\mathbf{4 8}$ hours of life. Archives of Disease in Childhood, 40, 430.

Anast, C. S. (1964). Serum magnesium levels in the newborn. Pediatrics, 33, 969.

Bajpai, P. C., Sugden, D., Ramos, A., and Stern, L. (1966). Serum magnesium levels in the newborn and older child. Archives of Disease in Childhood, 41, 424.

Bakwin, H. (1937). Pathogenesis of tetany of the new-born. American fournal of Diseases of Children, 54, 1211.

Baum, D., Cooper, L., and Davies, P. A. (1968). Hypocalcaemic fits in neonates. Lancet, $1,598$.

Davis, J. A., Harvey, D. R., and Yu, J. S. (1965). Neonatal fits associated with hypomagnesaemia. Archives of Disease in Childhood, 40, 286.

Gittleman, I. F., Pincus, J. B., and Schmertzler, E. (1964). Interrelationship of calcium and magnesium in the mature neonate. American fournal of Diseases of Children, 107, 119.

Graham, G. G., Barness, L. A., and György, P. (1953). Serum calcium and inorganic phosphate in the newborn infant, and their relation to different feedings. Fournal of Pediatrics, 42, 401.

Harris, R., and Tizard, J. P. M. (1960). The electroencephalogram in neonatal convulsions. Fournal of Pediatrics, 57, 501 .

Keen, J. H. (1969). Significance of hypocalcaemia in neonatal convulsions. Archives of Disease in Childhood, 44, 356.

Kobayashi, A. (1967). Neonatal hypomagnesaemia. Lancet, 2, 100.

Oppé, T. E., and Redstone, D. (1968). Calcium and phosphorus levels in healthy newborn infants given various types of milk. Lancet, 1, 1045.

Siggaard Andersen, O., Engel, K., Jorgensen, K., and Astrup, P. (1960). A micro method for determination of $\mathrm{pH}$, carbon dioxide tension base excess and standard bicarbonate in capillary blood. Scandinavian fournal of Clinical and Laboratory Investigation, 12, 172.

Spivek, M. L. (1956). Microchemical blood standards for normal 5-day-old newborn infants. Fournal of Pediatrics, 48, 581.

Stevens, J. F. (1965). Biochemical changes in the blood of the newborn. Fournal of Medical Laboratory Technology, 22, 47.

Todd, W. R., Chuinard, E. G., and Wood, M. T. (1939). Blood calcium and phosphorus in the newborn. American fournal of Diseases of Children, 57, 1278.

Willis, J. B. (1960). The determination of metals in blood serum by atomic absorption spectrophotometry. Spectrochimica Acta, 16, 259.

Correspondence to Dr. D. R. Harvey, Neonatal Research Unit, Hammersmith Hospital, Du Cane Road, London W.12. 